University of Nebraska - Lincoln

DigitalCommons@University of Nebraska - Lincoln

USDA National Wildlife Research Center - Staff Publications
U.S. Department of Agriculture: Animal and Plant Health Inspection Service

March 2004

\title{
The amount and economic cost of feral swine damage to the last remnant of a basin marsh system in Florida
}

\author{
Richard M. Engeman \\ USDA-APHIS-Wildlife Services, s_r100@yahoo.com \\ Henry T. Smith \\ Florida Department of Environmental Protection, Florida Park Service \\ Robert Severson \\ Savannas Preserve State Park \\ Mary Ann Severson \\ Savannas Preserve State Park \\ Stephanie A. Shwiff \\ USDA/APHIS/WS National Wildlife Research Center, stephanie.a.shwiff@aphis.usda.gov
}

See next page for additional authors

Follow this and additional works at: https://digitalcommons.unl.edu/icwdm_usdanwrc

Part of the Environmental Sciences Commons

Engeman, Richard M.; Smith, Henry T.; Severson, Robert ; Severson, Mary Ann; Shwiff, Stephanie A.; Constantin, Bernice ; and Griffin, Daniel , "The amount and economic cost of feral swine damage to the last remnant of a basin marsh system in Florida" (2004). USDA National Wildlife Research Center - Staff Publications. 332.

https://digitalcommons.unl.edu/icwdm_usdanwrc/332

This Article is brought to you for free and open access by the U.S. Department of Agriculture: Animal and Plant Health Inspection Service at DigitalCommons@University of Nebraska - Lincoln. It has been accepted for inclusion in USDA National Wildlife Research Center - Staff Publications by an authorized administrator of DigitalCommons@University of Nebraska - Lincoln. 


\section{Authors}

Richard M. Engeman, Henry T. Smith, Robert Severson, Mary Ann Severson, Stephanie A. Shwiff, Bernice Constantin, and Daniel Griffin 


\title{
The amount and economic cost of feral swine damage to the last remnant of a basin marsh system in Florida
}

\author{
Richard M. Engeman ${ }^{\mathrm{a}, *}$, Henry T. Smith ${ }^{\mathrm{b}}$, Robert Severson ${ }^{\mathrm{c}}$, Mary Ann \\ Severson ${ }^{c}$, Stephanie A. Shwiff ${ }^{a}$, Bernice Constantin ${ }^{d}$, Daniel Griffin ${ }^{c}$
}

\author{
${ }^{a}$ National Wildlife Research Center, USDA/Wildlife Services, 4101 LaPorte Ave, Fort Collins, CO 80521-2154, USA \\ ${ }^{\mathrm{b}}$ Florida Department of Environmental Protection, Florida Park Service, 13798 S.E. Federal Highway, Hobe Sound, FL \\ 33455, USA \\ 'Savannas Preserve State Park, 9551 Gumbo Limbo Lane, Jensen Beach, FL 34957, USA \\ 'USDA/APHIS/WS, 2820 East University Ave., Gainesville, FL 32641, USA
}

Received 22 May 2003; accepted 4 March 2004

\section{KEYWORDS \\ Alien species; \\ Damage estimation; \\ Economic value; \\ Exotic species; \\ Feral hogs; \\ Feral pigs; \\ Invasive species}

\begin{abstract}
Summary
Swine (Sus scrofa) have been introduced into many natural habitats throughout the world, and they have adversely affected the environment in most of those places. Basin marshes are unique, but dwindling ecosystems in Florida that are especially vulnerable to damage by feral swine. We estimated the amount of swine damage to the last remnant of a basin marsh system in Savannas Preserve State Park (SPSP), and to ecotones within the marsh. We also applied an economic valuation method for the swine damage that was based on the dollar amounts that wetland regulators have allowed permit applicants to spend in mitigation attempts to replace lost wetland resources. We found that swine damaged 19\% of the exposed portion of the basin marsh in our study area. Seventy percent of the sample sites showed swine damage at the shoreline and $58 \%$ showed damage at the interface with the upland vegetation of the adjacent mesic flatwoods. The area damaged within our study site alone was valued between $\$ 1,238,760$ and $\$ 4,036,290$. These damage valuation estimates were considered conservative, because it was impossible to incorporate values for such contingencies as swine impact to state and federally listed endangered plants in SPSP, some of which are found nowhere else in the world. We also could not extrapolate an economic quantity to describe the threat posed by the swine inhabiting SPSP as a reservoir for transmission of diseases to domestic livestock.

(c) 2004 Elsevier $\mathrm{GmbH}$. All rights reserved.
\end{abstract}

*Corresponding author. Tel.: +1-970-266-6091; fax: +1-970-266-6089.

E-mail address: richard.m.engeman@aphis.usda.gov (R.M. Engeman). 


\section{Introduction}

Feral swine (Sus scrofa) can be a particularly destructive exotic species in the places where they have been introduced (US Department of Agriculture, 1999). They impose a variety of negative environmental impacts through habitat degradation, predation on native species, and competition with native species (Choquenot, Mcllroy, \& Korn, 1996; Taft, 1999). Florida, along with Hawaii, is one of the two states of the United States with the most severe invasive species problems (US Congress, 1993), and swine were one of the first invasive exotic species to take hold in Florida. Florida is where swine were first introduced to North America, by DeSoto in 1539 (Towne \& Wentworth, 1950). The species possesses the highest reproductive potential of any large mammal in North America (Wood \& Barrett, 1979; Hellgren, 1999) and, with subsequent introductions, the range of feral swine in the US continues to expand (Gipson, Hlavachick, Berger, \& Lee, 1997). Feral swine currently inhabit many areas in such large numbers that they adversely impact wildland and agricultural ecosystems.

Feral swine often are the single greatest vertebrate modifier of natural plant communities (Bratton, 1977; Wood \& Barrett, 1979). Rooting may damage population structures of plants, set back succession, and change species composition (Bratton, 1977). In addition, mounting evidence indicates that swine help spread rootrot fungus (Phytophthora cinnamomi), which causes dieback disease in native vegetation (Kliejunas \& Ko, 1976). Habitat damage by swine is most pronounced in wet environments (e.g., Choquenot et al., 1996). Basin marshes are large, irregular, wet basins with outlets only during high water. Their shallow waters and exposed portions are dominated by herbs and shrubs (Florida Natural Areas Inventory, 1990), making them very attractive for foraging by swine. Water generally stands in the basins for only about 200 days per year, and they are associated with and often grade into wet prairies or marsh lakes (Florida Natural Areas Inventory, 1990).

Funding to manage feral swine and restore habitat is finite and must be carefully managed to optimise the positive impact on the protected resources. Decisions on management actions towards destructive invasive species are based on economic constraints, but the metric for success of management actions is measured in resource quality. Therefore, a means to efficiently estimate feral swine damage to habitats, and to apply a monetary value to the damage, would permit economic analyses to help guide and evaluate management actions. Here, we quantify habitat damage by feral swine to the exposed portions of the only significant basin marsh undisturbed by human habitat conversions in southeastern Florida. We also apply economic valuations to that damage.

\section{Methods}

\section{The basin marsh}

Savannas Preserve State Park (SPSP) protects the last remnant of extensive freshwater basin marsh systems that formerly extended for about $320 \mathrm{~km}$ along Florida's east coast. The SPSP basin marsh is unique in that water levels fluctuate dramatically from year to year, more so than in most basin marshes (Florida Department of Environmental Protection, unpublished data). The basin marsh in SPSP occurs in the form of a band about $0.6-1.3 \mathrm{~km}$ wide immediately west of the Atlantic Coastal Ridge for the length of the property (approximately $15.5 \mathrm{~km})$. Within the 570 ha of basin marsh, a mixture of grasses and sedges in shallow, open water dominates approximately $75 \%$ of the area, and sawgrass stands (Cladium jamaicense) cover the remaining $25 \%$. Because of its ephemeral nature, the SPSP basin marsh aquatic plant and animal communities are extremely sensitive to environmental disturbances. The fluctuating nature and gentle slope of the marsh also result in a wide, wet margin vegetated with forbs and grasses. This exposed zone is extremely attractive to swine for foraging and it is highly vulnerable to damage.

SPSP supports at least 516 species of vascular plants, 192 species of vertebrates, and 300 species of aquatic invertebrates (Florida Department of Environmental Protection, unpublished data). Thirty-five of these species are listed by the US Fish and Wildlife Service, Florida Fish and Wildlife Conservation Commission, or the Florida Department of Agriculture and Consumer Services as endangered, threatened, or of special concern (Florida Department of Environmental Protection, 2003).

\section{Study site and damage measurements}

Damage was sampled on transects spaced at $100 \mathrm{~m}$ intervals for $5.9 \mathrm{~km}$ along the periphery of the basin marsh. At each sample site, a tape measure transect was placed along the perpendicular distance from the water's edge to the interface between the marsh and upland vegetation of the surrounding mesic flatwoods community (Hartman, 
1978; Kautz, 1987). Both of these limits to the exposed portion of basin marsh were abrupt and easy to define. After placing the tape measure, three damage measurements were made. The first was the total distance under the tape that was damaged by swine. This amount could represent a single patch of damage or the combined distances under the tape of multiple patches. Damage not lying directly under the tape was not recorded. Swine damage was defined as ground overturned during foraging (rooting) activity. Tracks verified the species responsible. Armadillos (Dasypus novemcinctus) were the only other species in the park that could produce superficially similar (small) patches of damage, which were easily distinguished from swine damage by examining tracks and whether the ground was overturned, or dug by forefeet. The other two damage measures were binary and aimed at evaluating the damage precisely at the two habitat interfaces at the extremities of the transects. The point at which the tape contacted the water's edge was recorded as damaged or undamaged, as was the point at which the tape contacted the upland vegetation.

\section{Data analyses}

The percent damaged at each sample site was calculated as the ratio of the distance along the tape that damage patches comprised, divided by the length of the transect. The percent damaged along the basin marsh was calculated as the mean percent damaged among the sample sites $(n=60)$. The total exposed area of the study area was calculated as the mean transect length across the sample sites multiplied by the $5.9 \mathrm{~km}$ of shoreline. The damage rate along the shoreline was calculated as the percent of sample sites with damage at the water's edge. The damage rate at the upland interface was calculated similarly. Cochran's $Q$ test for single-factor repeated measures designs with dichotomous data (e.g., Winer, 1971) was used to examine whether the rate of damage was different at the two habitat interfaces.

\section{Damage valuation}

Determination of monetary values for protected habitats is not a straight-forward nor precise process. A means of applying a monetary value on a unit-area basis to damaged native habitats was needed to estimate the unit (per ha) and total cost of swine damage. Engeman, Shwiff, Smith, and Constantin (2002) discuss a variety of ways to apply monetary values to threatened and endangered animal species. Analogies to these methodologies were considered for application to habitat values, as well as other avenues specific to habitat issues. One simplistic consideration for valuation of habitat is to appraise the land on the basis of market value. However, special habitats such as wetlands have limited "market value", and if such habitat is selectively protected, the market value diminishes even further (King, 1998). The use of contingent valuation surveys for special habitats, analogous to those applied to endangered animals (Engeman et al., 2002), tend to be even more abstract appraisals of value (King, 1998). Estimated costs for restoring habitat to pristine condition (replacement costs) frequently produce values well in excess of the public's "willingness-to-pay", and therefore also do not represent a realistic valuation. The most defensible, logical, and applicable valuation for the damaged habitat characteristic of our study site was to use expenditure data for permitted wetland mitigation projects in the United States. Such data represent an empirical demonstration of willingness-to-pay value. King (1998) presented the dollar amounts per unit-area spent in efforts to restore a spectrum of wetland habitat types. The numbers represent the dollar amounts that environmental regulators, and to a degree elected governments, have allowed permit applicants to spend in attempts to replace lost wetland services and values (King, 1998). We identified the dollar value for the appropriate wetland habitat category from each of the two studies in King (1998). For these two studies, the habitat from our study would be classified as "freshwater emergent" or "openwater emergent", with respective 1997 empirical willingness-to-pay dollar values of $\$ 207,480 / \mathrm{ha}$ and $\$ 676,039 /$ ha (King, 1998). The 2003 values for each of these willingness-to-pay dollar amounts after adjusting for a $3 \%$ annual rate of inflation (Zerbe \& Dively, 1994) were $\$ 247,742 /$ ha and $\$ 807,226 /$ ha, respectively. The cost of the total area in our study site damaged by swine was calculated by multiplying the above values by the estimated area of swine damage.

\section{Results}

\section{Damage estimates}

The mean width of the exposed portion of the basin marsh was $44.7 \mathrm{~m}(\mathrm{SE}=4.9 \mathrm{~m})$. Multiplying this value by the $5.9 \mathrm{~km}$ distance of marsh periphery sampled resulted in an estimated total area of exposed basin marsh in our study site of 26.4 ha. The mean 
percent width of exposed marsh that was damaged by feral swine was $19.0 \%$, producing an estimated 5.0 ha of exposed basin marsh damaged by swine. The total value of the damaged area was $\$ 1,238,710$ when using the "freshwater emergent" valuation and \$4,036,130 when using the "openwater emergent" valuation.

Seventy percent of the sample sites showed damage at the water's edge, versus $58 \%$ at the upland shrub interface. However, this difference in damage rates was not detectable statistically $\left(\chi^{2}, 1\right.$ $\mathrm{df}=1.96, p=0.16)$.

\section{Discussion}

In Florida, a premium is placed on sanctuaries for protection and preservation of habitats and species, especially because much of the natural habitat in Florida already has been lost to development. We found a substantial proportion (19\%) of the exposed portion of the basin marsh to be damaged by feral swine. In estimating the monetary values of the swine damage to the habitat we assumed standard costs for restoration. The total value of the damaged area just within our study site ranged from $\$ 1.2$ million to $\$ 4.0$ million for the two wetland valuation classifications. These values are substantially underestimated if the potential economic spillover effects of feral swine management are extended to incorporate endangered and threatened species, water quality impacts, suburban development areas (swine leave the park and damage sod in neighboring developments), agricultural lands, domestic livestock, and the transmission of diseases. These spillover effects, or secondary multiplier effects, represent the indirect benefits to society of feral swine management through additional benefits of management that were not necessarily intended directly as an outcome of the project (Boardman, Greenberg, Vining, \& Weimer, 1996).

To expand on the above effects, consider that SPSP is home to dozens of threatened and endangered plant (and animal) species, as well as their unique habitats (e.g., Hartman, 1978; Gann, Bradley, \& Woodmansee, 2002), some of which are found nowhere else in the world (we do not identify the species or the specific areas in which these species are found to protect them from illegal collection). Damage to, or loss of, such a species is much more difficult to ascribe a monetary value to (Engeman et al., 2002). In fact, consider that values of endangered or threatened species have been deemed "incalculable" in US Supreme Court case law (Tennessee Valley Authority vs Hill, 1978). The opinion goes so far as to say "it would be difficult for a court to balance the loss of a sum certain-even $\$ 100$ million-against a congressionally declared 'incalculable' value, even assuming we had the power to engage in such a weighing process, which we emphatically do not."

The magnitude of potential damage costs by swine is further magnified if the definition of damage is broadened to include the potential for transmission of diseases to domestic livestock. Feral swine can harbor a number of diseases transmissible to livestock and/or humans (e.g., Becker et al., 1978; Choquenot et al., 1996; Romero \& Meade, 1999; Taft, 1999), and SPSP is situated at interfaces with rural lands, native habitats, and suburban development. In particular, the swine industry in the USA has nearly eradicated swine brucellosis and pseudorabies, but feral swine serve as a potential reservoir from which these diseases can be transmitted back to domestic stock (Taft, 1999). The swine damaging the SPSP basin marsh are geographically a potential reservoir for diseases that could be transmitted to domestic livestock in the area.

Thus, while we have provided monetary estimates on the value of swine damage to the exposed portion of the basin marsh, these values should be viewed as a lower bound on the value of potential ecological damage. As our study concluded, SPSP had commenced a contract with the US Department of Agriculture/ Wildlife Services for intensive swine removal throughout the park. The cost of this contract was $\$ 7500$, and represents only a minor fraction of the value of the swine damage to an average single ha of the exposed basin marsh, let alone to the additional costs of the swine damage. Continued monitoring for swine damage along the marsh is planned for future years and will determine the sufficiency of the applied level of swine management for slowing damage and promoting habitat recovery.

\section{Acknowledgments}

K. Fagerstone, N. Lance, and J.R. Mason provided insightful reviews of earlier drafts of this manuscript.

\section{References}

Becker, HN., Belden, RC., Brevault, T., Burridge, MJ., Frankenberger, WB., \& Nicoletti, P. (1978). Brucellosis 
in feral swine in Florida. Journal of the American Veterinary Medical Association, 173, 1181-1182.

Boardman, A. E., Greenberg, D. H., Vining, A. R., \& Weimer, D. L. (1996). Cost-benefit analysis: Concepts and practice. Upper Saddle River, NJ: Prentice Hall. 493pp.

Bratton, S. P. (1977). Wild hogs in the United Statesorigin and nomenclature. In G. W. Wood (Ed.), Research and management of wild hog populations (pp. 1-4). Georgetown, SC: The Belle W. Baruch Forest Science Institute of Clemson University.

Choquenot, D., Mcllroy, J., \& Korn, T. (1996). Managing vertebrate pests: Feral pigs. Canberra, ACT: Bureau of Resource Sciences, Australian Government Publishing Service. 163pp.

Engeman, R. M., Shwiff, S. A., Smith, H. T., \& Constantin, B. (2002). Monetary valuation methods for economic analysis of the benefit-costs of protecting rare wildlife species from predators. Integrated Pest Management Reviews, 7, 139-144.

Florida Department of Environmental Protection (2003). Savanas Preserve State Park Management Plan. Florida Department of Environmental Protection, Florida Park Service. Tallahassee, FL, 34pp.

Florida Natural Areas Inventory (1990). Guide to the natural communities of Florida. Tallahassee, FL: Florida Natural Areas Inventory and Florida Department of Natural Resources, 111pp.

Gann, G. D., Bradley, K. A., \& Woodmansee, S. W. (2002). Rare plants of South Florida: Their history, conservation, and restoration. Miami, FL: Institute for Regional Conservation. 1056pp.

Gipson, P. S., Hlavachick, B., Berger, T., \& Lee, C. D. (1997). Explanations for recent range expansions by wild hogs into midwestern states. Great Plains Wildlife Damage Control Workshop, 13, 148-150.

Hartman, B. J. (1978). Description of major terrestrial and wetland habitats of Florida. In H. W. Kale (Ed.), Rare and endangered biota of Florida, Vol. 2: Birds (pp. xvi-xix). Gainesville, FL: University Presses of Florida.
Hellgren, E. (1999). Reproduction in feral swine. In Proceedings of the 1999 national feral swine symposium. Austin, TX: Texas Animal Health Commission. pp. 67-68.

Kautz, R. (1987). Preliminary cover types for Landsat inventory. Tallahassee. FL: Florida Game and Freshwater Fish Comm. Office of Env. Serv., Nongame Wildlife Section.

King, D. (1998). The dollar value of wetlands: Trap set, bait taken, don't swallow. National Wetlands Newsletter. July-August: 7-11.

Kliejunas, J. T., \& Ko, W. H. (1976). Dispersal of Phytophthora cinnamomi on the island of Hawaii. Phytopathology, 66, 457-460.

Romero, C. H., \& Meade, P. N. (1999). Pseudorabies virus in feral swine, a research update. In Proceedings of the 1999 national feral swine symposium (pp. 73-74). Austin, TX: Texas Animal Health Commission.

Taft, A. C. (1999). Feral swine-national concerns. In Proceedings of the 1999 national feral swine symposium (pp. 25-26). Austin, TX: Texas Animal Health Commission.

Tennessee Valley Authority vs Hill (1978). 437 US 153.

Towne, C. W., \& Wentworth, E. N. (1950). Pigs from cave to cornbelt. Norman, OK: University of Oklahoma Press. 305pp.

US Congress (1993). Harmful non-indigenous Species in the United States. Office of Technology Assessment, OTA-F-565, Government Printing Office, Washington, DC, 391pp.

US Department of Agriculture (1999). Wild pigs hidden danger for farmers and hunters. Animal and plant health inspection services information bulletin 620 . Washington, DC, 7pp.

Winer, B. J. (1971). Statistical principles in experimental design. New York: McGraw-Hill.

Wood, G. W. , \& Barrett, R. H. (1979). Status of wild pigs in the United States. Wildlife Society Bulletin, 7, 237-246.

Zerbe, R. O., \& Dively, D. D. (1994). Benefit-cost analysis: In theory and practice. New York, NY: HarperCollins College Publishers. 